\title{
Coalition Politics Among Opposition Parties In Malaysia: A Case Study Of Pakatan Rakyat
} (2008-2016)

\author{
Nur Atika Bt Hairi \\ Department of Political Science \\ International Islamic University Malaysia (IIUM) \\ Kuala Lumpur, Malaysia \\ nuratikahairiiium@gmail.com
}

\begin{abstract}
This study examines the internal politics in Pakatan Rakyat (PR) component political parties (i.e., PKR, PAS, and DAP) as the coalition opposition parties in Malaysia from 2008 to 2015. The PR was the first coalition of opposition parties in Malaysia that managed to deny Barisan Nasional of their two-thirds majority in the 2008 general elections and won the popular vote in the 2013 general elections. This study is based on the assumption that there was a linkage between PR's strength and contributions and various challenges that the PR faced. Political conflicts that constrained the coalition stability in PR leading to its dissolution are investigated. The study employs Arend Lijphart's theory of consociational democracy as a framework for the analysis. The study argues that the PR as the opposition coalition in Malaysia was stronger than Barisan Alternatif (BA) or Pakatan Harapan (PH). The study found that hudud issues were the main factors that led to the dissolution of PR. However, it was also found that the main unifying element that kept the parties together in PR was the main leader in politics, Anwar Ibrahim. Given the findings of this study, to achieve better electoral results, opposition coalitions in Malaysia would need to work out a better strategy to accommodate component parties with diverse ideological positions.
\end{abstract}

Keywords-Barisan Alternatif, Pakatan Rakyat, Pakatan Harapan, Barisan Nasional, opposition parties, coalition, hudud, general election

\section{INTRODUCTION}

Malaysian politics is considered to be an ethnicbased politics. Ethnic-based politics means that they have ethnic political parties from the beginning. The first coalition politics in Malaysia was formed in 1955 in Malaysian government with practice the principle of the coalition by Lijphart's theory.

This is a case study of coalition building among opposition parties in Malaysia covering the period between 2008 and 2016. The main focus of the study is the opposition coalition known as Pakatan Rakyat (PR). The study aims to achieve the following objectives. First, this study will explain the nature of the party system in Malaysia. Second, it will analyze how Pakatan Rakyat dealt with the various political challenges that it faced. Third, it will examine the reasons for the dissolution of PR.

Malaysia is a multi-ethnic country with a relatively high percentage of minorities. By 2015, Malaysia's total population had increased to more than 30.3 million. In 2015, Bumiputeras constituted $62.04 \%$ of the population while Chinese constituted 22.78\%; Indians, 6.60\%; and other Malaysians $0.99 \%$. Non-Malaysian citizens account for 2.6 million people, or $8.58 \%$ of the country's population [1].

Coalition building is, therefore, an important strategy used by political parties to unite and attract support from the different communities in the country. Pakatan Rakyat (PR) was a coalition among the opposition parties in Malaysia which included the Parti Tindakan Demokratik (Democratic Action Party- DAP), Parti Keadilan Rakyat (People's Justice Party- PKR) and Parti Islam Se-Malaysia (PAS). PR was initially formed in 2008 and continued to exist until 2015 as a reconstitution of the previously existing opposition coalition known as the Barisan Alternatif (BA).

The study seeks to examine the strengths and the weaknesses of the Pakatan Rakyat (PR) coalition and the factors that led to the breakdown of the PR in 2015 [2]. The analysis will help identify some important trends that have shaped the opposition coalition politics in Malaysia in recent history.

The strength of a coalition depends on its internal cohesion. In the case of PR, the leadership of Anwar Ibrahim was an important binding factor for the PR component parties. As the de facto opposition leader in Malaysia, Anwar Ibrahim helped to provide leadership which maintained unity in the PR coalition while emphasizing moderation [3]. The unity in the PR coalition helped the PR to obtain impressive election results in the 12th and 13th Malaysian general elections.

"Moderation" was an important binding theme in PR politics which involves a steeply secular DAP and a committed Islamist party PAS, working together under the same coalition. Having a background in 
Islamic youth politics in Malaysia, and being a former Deputy Prime Minister of Malaysia, Anwar personified moderation among the PR followers. Anwar's imprisonment in 2015 following a court case seriously affected the stability and unity within the PR. In addition to the impact of personalities on PR, this study examines how component party ideologies in the PR shaped the fate of the coalition.

\section{THE PARTY SYSTEM IN MALAYSIA}

\section{A. Malaysia: A Dominant Party System (1957- 1998): Barisan Nasional (BN)}

Malaysia practices a system of government based on Parliamentary Democracy and adopts Constitutional Monarchy (Moten, 2013). The head of state is called Yang Di Pertuan Agong (YDPA). Art. 32 (1) states that: "There shall be a supreme head of the Federation, to be called the YDPA, who shall take precedence over all persons in the Federation and shall not be liable to any proceedings whatsoever in any court except in the special court established under Part XV of Constitution, Act No. 848." Unlike other monarchies where the crown is hereditary, the YDPA is elected after a five-year period [4]. Parliamentary Democracy is a system where the government is freely elected by the people through elections and is therefore accountable to the people. It is a form of government in which the executive branch is responsible to and is drawn from the legislature [5]. Democracy in Malaysia has not yet been fully implemented. However, Malaysia allows political parties to participate in the general election according to their wills, and give them a chance to run their campaigns [6].

Barisan Nasional $(\mathrm{BN})$ has been appointed as the government which has administered Malaysia for more than half a century. It also has representatives from all ethnics in Malaysia. United Malays National Organization (UMNO) was founded in 1946 by Dato 'Onn Jaafar to protect the Malay interests. The Malaysian Chinese Association (MCA) was formed to protect the Malaysian Chinese interests, and the Malaysian Indian Congress (MIC) was established in 1946 to represent the Indian community [7]. The monopoly by $\mathrm{BN}$ as a single ruling party since independence was broken when the opposition parties formed a coalition among them in the 1999 Malaysian general election. Moreover, the nature of party system in Malaysia almost changed into the two-party system when Pakatan Rakyat (PAS, DAP, and Keadilan) established.

\section{B. Broken Monopoly: From Barisan Alternatif (BA) to Pakatan Rakyat (PR)}

The impetus for the BA's formation was the 20 September 1998 arrest and subsequent conviction of former UMNO deputy Prime Minister Anwar Ibrahim, who had been fired from his government posts and subsequently became the leader of the Reformasi movement against UMNO [8]. The main actors in Barisan Alternatif (BA) and Pakatan Rakyat (PR) were almost the same individuals which are DAP, and PAS as the members. However, the differences between them are during BA, PKR was involved in the 10th Malaysian general election (GE10) on the ticket of the National Justice Party (PKN) and Malaysian People's Party (PRM). PKR was formed in 2003 by a merger of the National Justice Party (PKN) and the Malaysian People's Party (PRM). Therefore, BA had four component parties which were DAP, PAS, Keadilan, and PRM during its early establishment and was involved in 10th Malaysian general election (GE10). BA only had two component parties during 11th Malaysian general election (GE11) which were PAS and PKR [9].

The key for success in the 1999 general elections was the leaders among them especially PAS and DAP understood the fragility of their partnership under the Barisan Alternatif (BA) banner and agreed to focus on economic equality, social justice, and transparency. For example, the Asian financial crisis in 1997 split the Barisan Nasional government between supporters of the Prime Minister, Mahathir Mohamad, and his deputy, Anwar Ibrahim. Mahathir's sacking of Anwar in 1998 provoked widespread opposition, which PAS capitalized on more than any other opposition party [10]. Members of both acknowledged the critical role that Anwar plays in holding the alliance together, especially when Barisan is doing its best to break it apart [11].

Unfortunately, the alliance of Barisan Alterntif (BA) during 11th Malaysian general election (GE11) had been strained by PAS's when PAS renounced its aim of making Malaysia an Islamic state but did not include this issue in the joint manifesto. Not only that, but they also assumed that Lim Kit Siang and Karpal Singh lost their constituencies mostly because of its largely Chinese electorate's distrust of the alliance with PAS [12]. The loss of Anwar Ibrahim as the main leader of BA is the most important factor for the breakdown of the BA. Barisan Alternatif (BA) was disbanded after the 2004 general elections, and a new coalition was formed, People's Front (Barisan Rakyat, BR) following the 2008 general elections.

The name Barisan Rakyat was also converted to Pakatan Rakyat (PR) after the 2008 general elections [13]. The first PR convention was held in 2009 in Shah Alam and the second was held in Penang in 2010. PR had no organization but appointed Shabrimi Sidek as PR Secretary [14]. The coalition was formed among the opposition parties in Malaysia such as PKR, DAP and PAS to breakdown $\mathrm{BN}$. The PR, despite making significance inroads into Malaysian political setting, could not pose a serious challenge to the ruling $\mathrm{BN}$ government in the 
state [15]. In PR's perspective, people should be aware that, the five pillars are preserved and do not change, no matter who rule in Putrajaya. The five principles are the institution of the Malay Rulers as Head of State, Islam as the official religion, Malay as the National Language and Special Position of the Malays and indigenous people [16]. There were three key documents of the opposition coalition Pakatan Rakyat. The first is Common policy framework and second is Pakatan's joint policy statement, better known as the Buku Jingga (Orang Book). Finally, there is the list of immediate reforms it has pledged to implement within 100 days of taking over the federal administration [17].

\section{The Performance of Pakatan Rakyat (PR) in 2008 and 2013 General Election}

Many political strategies have been introduced for extensive coalition building in PR since the 2008 general election such as rebuilding the unity among opposition parties and consolidation between them, especially in order to make any decision [18]. The results of the 2008 general election on March 8, 2008 was unexpected and surprising to everyone and drew some of the first in the history of politics Malaysia [19]. The changes in behaviour and orientation of voting in the 2008 general election is referred by most major media and online communities as a wave of "political tsunami" [20].

The unexpected result of 2008 general election was due to dissatisfaction among the Malaysian people with the government which led them to choose other parties. The opposition parties took advantage of this situation and started on coalition building by forming Pakatan Rakyat (PR). DAP and PAS appeared to get a new paradigm when Anwar Ibrahim became the PKR's advisor. He had a strong influence because he was the former Deputy Prime Minister, the Deputy President of UMNO, Barisan Nasional members of the cabinet and once previously as the main leader of Angkatan Belia Islam Malaysia (Muslim Youth Movement of Malaysia- ABIM)[21]. Pakatan Rakyat won 82 of the seats in the parliament or $36.9 \%$ of the parliamentary seats. According to the Election Commission, about $70 \%$ of Malaysia's 10.9 million voters casted their ballots. The ruling coalition, Barisan Nasional (BN) won $51.2 \%$ of the popular vote against $64 \%$ in the 2004 polls which was a reduction in performance, while the opposition improved its performance from $9 \%$ to $37 \%$ [22].

The 13th general election was the election of the most intense in the history of elections in Malaysia because of the consolidation of PR and rise of a young generation demanding a transition of power that had been dominated by Barisan Nasional. The young people wanted a change of the government under the leadership of the Pakatan Rakyat under the leadership of Anwar Ibrahim [23]. The moderation that was propagated by Anwar with his idealism gave a new momentum and a big impact on the opposition parties in Malaysia particularly on how he became the middle person who unites DAP and PAS, especially among the leaders of both parties such as Nik Aziz, Hadi Awang, Lim Kit Siang, Lim Guan Eng and Karpal Singh [24].

In the 13th general election, the opposition coalition PR won more of the total number of votes, with a tally of 5,623,984 (50.87\%) of the popular vote but only 89 parliament seats $(40.09 \%$ of the total). In contrast, BN had picked up 5,237,699 though garnering $47.38 \%$ of the popular vote. BN won 133 federal seats, thus retaining Parliamentary control with $59.91 \%$ of the seats. BN indeed won only $45.55 \%$ of the popular vote and $51.55 \%$ of the seats in West Malaysia, with Sabah and Sarawak together contributing nearly $30 \%$ of the total number of seats won by BN (Mohd Nawab, Saravamuttu, Hock and Johan, 2016, p. 77). But, due to PR first- past- the- post electoral system, BN had won $60 \%$ of the seats to take the majority in Parliament [25].

In brief, although the main actors Barisan Alternatif (BA) and Pakatan Rakyat (PR) are almost the same, their impacts are very different. Barisan Alternatif cannot deny two-third majority BN like PR. Pakatan Rakyat was the coalition of opposition political parties that continued to put pressure on the Barisan Nasional (BN) during the Malaysian general elections from 2008 until 2013.

\section{CONSOCIATIONALISM AS A POWER- SHARING APPROACH ("CONSOCIATIONAL DEMOCRACY” BY LIJPHART)}

The coalition is a good one that stepped for opposition parties. Therefore, 1999 that was started for opposition parties in Malaysia formed the coalition with namely, Barisan Alternatif (BA). The opposition parties realized that this action can also give their victory if they applied this theory. Lijphart introduced consociationalism as the power-sharing approach that was implemented in Pakatan Rakyat in 2008. PR leader used the elements in a consociational democracy which are grand coalition among all ethnic groups, mutual veto in decision making, ethnic proportionality in the allocation of certain opportunities, offices and segmental autonomy [26].

Coalition politics is a process by which parties come together to form a coalition with similar values and goals combining their resources and agree to help each other. A coalition is a temporary alliance or partnering of groups in order to achieve a common purpose or to engage in joint activity [27].

Coalition politics plays a central role in all of the three types of power which are threats, exchange, and integrative power. This is because groups of people who pool their resources and work together to advance their common interests are 
generally more powerful than those who do not. It is also true that groups of people who fight among themselves are less capable of advancing their interests than those who are able to work together. Therefore, coalition politics is a classic win-win strategy which can help parties involved in many different situations. The impact of this is that it makes each group much more powerful than they used to be when they were acting alone. If coalition politics is successful, it may be able to dramatically change the power balance and help the coalition members to successfully resist threats or make effective counter threats [28].

\section{THE GENERAL OVERVIEW OF INDONESIA AND THEIR SIMILARITIES TO MALAYSIA}

The coalition is also formed in Indonesia. According to Uhlin (1998) cited in Eklof (1999), on May 21, 1998, the New Order regime emerged, and the people started to understand about the party and the coalition [29] [30]. According to Mietzner (2014) and Tapsell (2015), Indonesia had two coalitions and one neutral party (Democratic Party) in 2014 Indonesian General Election [31] [32]. Great Indonesian Coalition (KIH) was a coalition of political parties to support Joko Widodo-Jusuf Kalla in the presidential election in 2014. The coalition consisted of the PDI-P, National Awakening Party (PKB), National Democratic Party (NasDem), People's Conscience Party (Hanura) and Indonesian Justice and Unity Party (PKP Indonesia). This coalition was declared during the Declaration of Jokowi-JK on 19 May 2014 in Jakarta. From the opposition's side, the Red White Coalition (KMP) was formed to support Prabowo-Hatta Rajasa in the election in 2014. In its early formation, this coalition consisted of Great Indonesia Movement Party (Gerindra), National Mandate Party (PAN), United Development Party (PPP), Prosperous Justice Party (PKS), Crescent Star Party (PBB) and the Golkar Party. The coalition government was getting stronger when PPP, PAN and Golkar Party quit the coalition among the opposition parties. This started with PPP in October 2014, followed by the PAN in September 2015, and Golkar in January 2016 [33]. These three parties expressed support for the government and joined the Indonesian Great Coalition and later known as the Cooperation Coalition Government Support Party (KP3). James Siegel wrote in his book "Indonesia: A Partial Appraisal," that with the combination of PPP and PAN the Coalition of Great Indonesia turned into a majority in Parliament, with 295 seats, compared with the Red White Coalition with 204 seats and Democrats with 61 seats [34].

\section{THE OPPOSITION IN MALAYSIA: CHALLENGES AND OPPORTUNITIES}

Based on the track record of the Malaysian general elections performance in 2008 and 2013, Pakatan Rakyat (PR) seems to have been successful in influencing and attracting the people.

Many strategies and platforms have been used by Pakatan Rakyat (PR) to sustain and win in the general elections. The combination of Parti Islam Se-Malaysia (Pan-Malaysian Islamic Party- PAS), Parti Keadilan Rakyat (People's Justice Party- PKR) and Democratic Action Party (DAP) makes a big impact on utilizing their members to achieve the mission and vision of Pakatan Rakyat. However, there have been a lot of various political challenges that it faced in order to maintain strength and coalition among them.

Many ways or techniques Pakatan Rakyat deal with, besides various internal and external political challenges that it faced. The internal challenges refer to the conflict or any issues among DAP, PAS and PKR such as fundamental ideological differences which is a clash of ideologies, common policy framework, distribution of seats, manifesto, campaigns and the Selangor Chief Minister crisis (2014). Political attacks from an incumbent party which is Barisan Nasional (BN) and the people are also analyzed as the external challenges that it confronted.

The issues confronted by Pakatan Rakyat (PR) were indeed as the measurement of the key performance index (k.p.i) for the organization of the Pakatan Rakyat (PR). The leaders of Pakatan Rakyat (PR) knew and interpreted their strengths and weaknesses based on the ways they handle, control and solve any problems or challenges whether among them or political attacks from incumbent party, or the people. The internal and external issues can become threats or opportunities for Pakatan Rakyat (PR). The people evaluated the stability and coalition in Pakatan Rakyat based on the action of leaders in Pakatan Rakyat (PR), especially regarding the fundamental ideological differences and distribution of seats [35].

\section{A. Fundamental Ideological Differences}

PKR as a helper attempts to convince the people to believe that Pakatan Rakyat is not practicing racism. PKR has reduced the fundamental ideological differences especially between PAS and DAP by its leadership. For instance, PKR gives equal chances to all ethnic groups to run for the vice presidential position representing the Chinese, Indian, Sabah and Sarawak such as Tiang Chua who won the nomination as the Vice President of PKR. Moreover, many PKR leaders in Perak and Perlis who are Malaysia Chinese can easily wear the "songkok." Malay costumes and all other things. In brief, PKR helped Pakatan Rakyat to maintain still as a multiracial party which is dominated by the Malays 
but included other ethnic groups like Malaysian Indian and Chinese.

In addition, the PAS leaders during in Pakatan Rakyat, were categorized into ulama, professional, conservative and neo-conservative especially by non-Muslims [36]. The multi backgrounds of leaders were reflected on the ways PAS is addressing issues concerned with religion and unity. These include the use of the word Allah (God), the law involving non-Muslims going to the mosque, politics in the mosques, the law of non-Muslim reading the verses of the Quran, and others. Therefore, the initiative by Mujahid to establish the PAS Supporters Congress (Dewan Himpunan Penyokong PAS) on 23 May 2010 allowed supporters among the non-Muslims to have more opportunities to give views and opinions in PAS [37].

DAP also contributed to reduce the fundamental difference. During the Parliamentary election of Teluk Intan in May, 2014, Dyana Sofya Mohd Daud was chosen as the candidate from DAP and the representative from Pakatan Rakyat. It clearly showed that DAP did not only represent the Chinese people, but also accepted the Malays to join them [38].

\section{B. Distribution of Seats}

Pakatan Rakyat has instructed each state to discuss the distribution of seats among the component parties. If negotiations cannot be resolved at the state level, the problem would be resolved by carrying it to the top leadership of PR [39]. PR leaders held a meeting among them once a month [40]. Most of the total distribution of seats was the same as the 12th general election. For examples, the negotiations on the allocation of seats among the coalition government in Selangor concluded with a decision to maintain the status quo in the 12th general election. PKR remains contested in 21 seats, PAS in 20 seats and DAP in 15 seats [41].

The 12th general election has many probability results since this is the first general election for PR. Therefore, techniques that are used by $\mathrm{PR}$ in 12th general election is putting the candidates from DAP in the Malaysian Chinese majority areas, PKR in mix seats, or the Malay majority and PAS in the Malay majority. Besides of that, PR also looks at the urban development category. For instance, PKR represents the most number of urban Malay voters, DAP and PKR are located in urban and semi-urban seats, and PAS that represents the Malay voters in PAS seats are in Kelantan and Terengganu. The total of parliaments' seats in 2008 is 211 . The result of distribution of parliaments seats among PR parties are as the following: PKR's seats are 97, PAS's seats are 67 and DAP's seats are 47 [42].

In regard to the 13th General Election, the probable total voters is reported to be: $52.63 \%$
Malay, 29.68\% Chinese, $7.31 \%$ Indian, $8.96 \%$ Bumiputera (non-Malay) and $1.43 \%$ others [43]. PR believed that they even cross the ethnic groups, Malay voters will be the deciding force in future elections. The total of parliament's seats in 2013 is 223. The result of the distribution of parliaments seats among PR parties are as the following: PKR with 99 seats, PAS with 73 seats and DAP secured 51 seats [44].

In brief, Pakatan Rakyat (PR) component parties in 12th and 13th Malaysian general election are the same except for PAS that increased from $32 \%$ to $33 \%$ and DAP that decreased from $23 \%$ to $22 \%$.

\section{The Selangor Chief Minister Crisis (2014)}

The major crisis about the Selangor Chief Minister in 2014 almost brought down the Selangor state government, and the people were very disappointed with the leaders from DAP, PKR and PAS due to the failure of the leaders to solve this problem.

The seizure of chief minister of Selangor crisis erupted starting with "Kajang Move" initiated by the PKR strategic director Rafizi Ramli in the election of (PRK) Legislative Assembly (DUN) Kajang in March, who aimed to be made the Chairman of the party, and Anwar Ibrahim as the new Menteri Besar Selangor. Kajang lost its MP who won the seat in the 13th general election when Lee Chin Cheh resigned to make way for Anwar to contest in the by-election. However, Anwar's intention was stagnated when he failed to be the Kajang state seat candidate after the court found him guilty of sodomy. As a result, his wife as PKR president, Wan Azizah Wan Ismail, replaced him for the seat. Wan Azizah won the Kajang by-election, defeating BN candidate Chew Mei Fun with a majority of 5,379 votes. Wan Azizah obtained 16,741 votes while Mei Fun had 11.362 votes [45].

However, despite winning the Kajang byelection, Wan Azizah was still unable to be the chief minister because Abdul Khalid Ibrahim still wanted to continue with his job refusing to resign. To make it worse, Wan Azizah did not get the green light by the Sultan of Selangor, Sultan Sharafuddin Idris Shah to replace Abdul Khalid. Before that, Wan Azizah had announced that she had received the support of 30 assemblymen from Pakatan to allow her to replace Abdul Khalid as the new chief minister of Selangor [46].

Since the story of PKR wanting to get rid of Abdul Khalid as chief minister, PAS was seen as a major obstacle. After the PKR fired Abdul Khalid, PAS nominated another candidate for the post of chief minister. PAS believed that the candidate should be from PKR who had agreed to lead the Pakatan Rakyat government in Selangor. PAS rejected Wan Azizah as the candidate, and they proposed another person. The character or response from PAS made DAP to issue various statements 
that questioned this party. For DAP, PAS was a traitor because they continued performing executive duties as usual. Hadi was also seen as a traitor as he went against the decision made in the Pakatan Rakyat Leadership Council on the nomination of Wan Azizah Wan Ismail as the sole candidate for Pakatan Rakyat for Chief Minister of Selangor. This conflict caused a major crisis and almost brought down the state government [47].

After several months of the chief minister of Selangor crisis, it found its endpoint when the PKR deputy president Mohamed Azmin Ali announced that the palace had consented for him to replace Abdul Khalid [48]. PAS, DAP, and PKR agreed to appoint him as a new Selangor Chief Minister. The membership of Abdul Khalid had been terminated by the PKR's disciplinary committee after refusing to give way to Wan Azizah Wan Ismail to be appointed as the new Menteri Besar [49].

However, Pakatan Rakyat also successfully won people's confidence by countering with the rise and focusing on the big issues, especially on what the people want. Besides, they also focused on issues related to the development of the country such as the fuel's price, the abolition of the toll, abolition of ISA, the system of education, Malaysia's corruption scandal, 1MDB national debt and so on [50].

The unity and strong relationship between the leaders of Pakatan Rakyat are also considered as the ticket for winning the people's confidence. The high tolerance and negotiations among them as the main spirit for PR dealt with various political challenges and sustained from 2008 until 2015. Each party in PR had their own strengths and became complementary to each other.

\section{THE COLLAPSE OF THE PAKATAN RAKYAT (PR)}

The coalition tensions and stresses caused the Pakatan Rakyat to dissolve. There were differences of views among the people in political issues and the management of life when they directly involved politics, administration, and state. The extreme differences would lead to conflict. Political conflicts as mentioned in previously of this study may occur due to clash of or differences in ideology, custom, self-interest, party interest and so on. Political conflict is a normal problem that usually arises in societies and brings them into serious disagreements.

Finally, it causes the breakdown of the coalition, unity or alliance of the party that consequently leads to strife and quarrel with each party, especially among the leaders. This situation was similar to what happened to the Pakatan Rakyat (PR) [51].

\section{A. De Facto Leader of Anwar Ibrahim}

The first reason for this problem when lost the leader of the authoritative leader in organization. When
Anwar Ibrahim was jailed, the other leaders and the committee lacked direction or lost their parent. Pakatan Rakyat (PR) still does not have stability among them even though they have other senior politics like Nik Aziz, Karpal Sigh, Lim Kit Siang or Abdul Hadi Awang [52].

Referring to the history of Parti Islam SeMalaysia (Pan-Malaysian Islamic Party- PAS) and Democratic Action Party (DAP), they have been struggling for decades but could never gain a twothirds majority in the parliament based on the strength of their own party. However, after Anwar Ibrahim was released from the prison, he only took four years to deny the two-thirds majority of Barisan Nasional (BN) in the parliament. Besides, the character of Anwar Ibrahim in terms of built strategy and diplomacy succeeds in uniting the Pakatan Rakyat (PR) through Parti Keadilan Rakyat (People's Justice Party- PKR). The impact from Anwar's victory was that it did only increase the image of PR, but became the glue that binds PR members.

Unfortunately, when he was held in jail, the unity broke down. The final decision was made unanimously by a panel of five judges headed by the Chief Justice Arifin Zakaria, who upheld the conviction and imprisonment of five years for him. With the decision, Anwar was disqualified as a representative for Permatang Pauh MP as provided under the Federal Constitution. The elected representatives can be dismissed from the seat if fined more than RM 2,000 or jailed for more than a year [53].

\section{B. Islamic State and Implementation of Hudud}

The second factor that resulted in the breakdown of Pakatan Rakyat (PR) appeared when PAS rose up again by the intention to implement the Islamic state and hudud. The Islamic state and hudud are actually one of the PAS mission. PAS was eager to implement sharia crime legislation in Kelantan which was approved in 1993. It means that the coalition must be well aware of the principles of PAS. The PAS respected and agreed with DAP and other political parties principles. This issue of implementation of sharia legislation was raised last year when PAS president, Abdul Hadi Awang presented a Private Member's Bill in Parliament to amend the Syariah Courts (Criminal Jurisdiction) Act - or Act 355- to enhance punishments in Syariah Courts. That being said, non-Muslims should not fear Act 355 because it would solely apply to Muslims only. The Federal Constitution established the jurisdiction of the Syariah Courts to Muslims only, and Act 355 Section 2 clearly stipulates that only Muslims shall be triable and punishable in the Syariah Court. Although PAS take action based on the hukm (law), they joined the coalition under tahaluf siyasi (political cooperation). The original tahaluf siyasi is haram (prohibited) for any non- 
Islamic parties. However, ulama allowed it as long as the condition of Islam is not blocked and fought against [54]. There are three basic principles being upheld by PAS which are defending the sharia Islam, fighting for the rights of citizens and developing the country by peaceful means [55].

Not only that, but PAS also listed six conditions for a coalition one of which was breached by the DAP. As a result, Pakatan Harapan was born following this tragedy and the leaders of PKR divided into two teams, where one side supported PAS and the other went with DAP. According to PAS secretary-general, Takiyuddin Hassan, Pakatan Harapan and Pakatan Rakyat can co-exist. That situation existed at one time when PAS cooperated with Parti Melayu Semangat 46 led by Tengku Razaleigh Hamzah. In the 1990s, PAS was in Angkatan Perpaduan Ummah (APU) and at the same time Semangat 46 cooperated with DAP, Parti Bersatu Sabah and Parti Rakyat Malaysia through Gagasan Rakyat [56].

According to Syahidulamri, the relationship among PR members worsened after the Malaysia Islamic Scholars Conference (Multaqa Ulama Se-Malaysia- MUS) was held in 2013. One of the resolutions of MUS is to revise tahalluf siyasi in PR especially with PKR. After that, MUS II was held in 2015 at Stadium Tertutup MPSJ, Selangor. One resolution in MUS II is to support the state of Kelantan to bring Private Bill (RUU) to parliament for the implementation of hudud although it received objections from PKR and DAP. Furthermore, the election for PAS leadership also influenced the decision whether to break up or not with PAS. It is because most of the leaders in PAS center are those from a religious background. The members of PAS from the professional and neo-conservative background are not appointed as leaders anymore. These include Mujahid Rawa, Mohammad Sabu and others who are more pro PR than those in conservative or religions scholar categories that decide to break up with DAP in PR. During the 61st PAS General Meeting (Muktamar PAS ke-61), PAS Ulama Council approved the proposal to break up with DAP and PAS Congress subsequently approved the proposal without debate. It received a negative reaction from DAP when the party acted by ordering PAS members who were holding posts in Penang government to resign. This decision is opposed to the view of Nik Abdul Aziz. He reminded PAS to go forward through understanding the political condition in Malaysia and showing the value of Islam among the non-Muslims [57].

Bakashmar (2016) argued that the debates are one alternative or instrument for delivery content about the legally Islamic criminal law (or hudud law) if needs to be implemented in any of Malaysia's thirteen states. The debates can be held through the mainstream media, social media, in the state and federal parliaments, and in civil society [58].

This issue was not considered as a big deal during the time of PAS in Pakatan Rakyat (PR) because PR mission was similar to the concept of an Islamic state but in a different name. PR used slogan "Negara berkebajikan (The welfare state)". The welfare is one of the principles of Islamic state theory. The situation became worse when Hadi Awang showed the eagerness to implement Islamic state and hudud by fanaticism character. His character is a symbol indicating that this is the final decision without a change. There is less explanation from PAS (tahaluf siyasi) to Pakatan Rakyat component parties and the people acquire negative perception towards PAS.

When this crisis became complex, the clash of ideologies happened and became one of reasons for the dissolution of PR. The struggle among them reflected personalities of each of the leaders in PR. As a result of this, the leaders of PR cannot decide to agree or disagree with others' opinion which causes disunity. The situation became worse when the leaders only focus to personal or party interest rather than issues related to the nation. In sum, when the clash of ideologies happened, the leaders showed the less approachable behavior and became less transparent. And finally, there are no longer issues to be concerned about.

\section{CONCLUSION}

The political conflict, if not handled properly, will lead to destruction. However, if it is treated properly and wisely, it will bring very positive results. But, if it is treated improperly and arrogantly, it will bring very negative results and this what happened to Pakatan Rakyat (PR). PR ended on 16th June 2015 when the conflict and issues were not settled among them, especially between PAS and DAP.

Later, Pakatan Harapan (PH) was established by the coalition among PKR, DAP and a new party which is Parti Amanah Negara (National Trust Islamic Party- PAN) a few months after the dissolution of PR. PAN is a splinter party from PAS. Then, Parti Pribumi Bersatu Malaysia (PPBM) is a splinter party from BN was joined in $\mathrm{PH}$ in 2017 [59]. The PH was built as a platform for the coalition of opposition parties in Malaysia and as a replacement to PR.

The coalition in Pakatan Rakyat (PR) is the best place performance for opposition parties which are PAS, PKR and DAP. Even though PR could not beat the $\mathrm{BN}$ in terms of power in all the states, this coalition put considerable amount of pressure on the $\mathrm{BN}$. This was shown through the different results of the general elections held from 2008-2013. As a consequence, the ruling $\mathrm{BN}$ parties had to work harder to gain support from voters at that time rather 
than right now when Pakatan Harapan (PH) was not stronger than PR.

The power-sharing that applied in Pakatan Rakyat brings benefit to PAS, DAP and PKR in general elections. Therefore, the necessary implementation of coalition's theory among the opposition parties.

\section{References}

[1] Ministry of Human Resources. (2015). Statistics of Employment and Labour. Malaysia. Retrieved from http://myhos.mohr.gov.my/ebook/istatistik2_2015/bil 2_2015.pdf

[2] Mohd Nawab, Saravamuttu, Hock and Johan. (2016). Coalitions in Collision: Malaysia's 13th General Elections. Petaling Jaya: Strategic Information \& Research Development Centre.

[3] Nathaniel, T. \& John, L. (2008). Political Tsunami: An End to Hegemony in Malaysia. Kuala Lumpur: Kinibooks.

[4] Zartman, I. (2001). Islam, the State and Democracy. United Kingdom: Cambridge University press.

[5] Tahir, M. N. (1994). Comparative Study of the Role of the Head of State in Parliamentary and Presidential Systems of Government. (Ph.D). IIUM.

[6] Farish Ahmad, N. (2014). The Malaysian Islamic Party 1951-2013: Islamism in a Mottled Nation. Netherlands: Amsterdam University Press.

[7] Mauzy D. K. (1983). Barisan Nasional: Coalition Government in Malaysia. Marican \& Sons (Malaysia). Malaysia.

[8] Khoo Boo. (2003). Beyond Mahathir: Malaysian politics and its Discontents. United Kingdom: Zed Books.

[9] Kamarudin, J. (2000). Pilihanraya 1999 dan Masa Depan Politik Malaysia. Kuala Lumpur: IKDAS.

[10] Hilley, J. (2001). Contesting the Vision: Mahathirism, Hegemony and the New Opposition in Malaysia. New York: Zed Books.

[11] Kamarudin, J. (2000). Pilihanraya 1999 dan Masa Depan Politik Malaysia. Kuala Lumpur: IKDAS.

[12] Moten, R. A. (2009). 2004 and 2008 General Elections in Malaysia: Towards a Multicultural, Biparty Political System?. Asian Journal of Political Science, $\quad 17(2)$ 173-194. http://dx.doi.org/10.1080/02185370903077469

[13] Malaysiakini. (2002). BA Yakin Barisan Rakyat Dapat Sokongan Semua Parti Pembangkang: Ruslan. Retrieved 15 July 2016, from https://m.malaysiakini.com/news/11525

[14] Husin, S. A. (2012). Memoir Perjuangan Politik Syed Husin Ali. Petaling Jaya: Strategic Information and Research Development Centre.

[15] Nurul Izzah, A. (2014). Masa Depan Masa Kita!. Selangor: Grup Buku Karangkraf Sdn. Bhd.

[16] Tricia Yeoh \& Amin. (2011). Liku-liku Peformasi Pakatan Rakyat di Selangor. Petaling Jaya: Strategic Information and Research Development Centre (SIRD).
[17] Chin Tong, L. (2013). Middle Malaysia: Centre Ground is Battle Ground. Kuala Lumpur: Genta Media.

[18] Weiss, M., L. (2005). Protest and Possibilities: Civil Society and Coalitions for Political Change in Malaysia. Palo Alto: Stanford University Press.

[19] Amer Saifude, G. (2009). Geografi Pilihanraya Malaysia. Kuala Lumpur: Penerbit Universiti Malaya.

[20] Nadzri, M. M. (2009). Politik Malaysia di Persimpangan: Praktik Politik dalam PRU 2008 dan Kontemporari. Petaling Jaya: Strategic Information and Research Development Centre.

[21] Kim Quek. (2005). Where to, Malaysia: A future with Anwar's Reformasi or back to Mahathirism. Petaling Jaya: Strategic Information and Research Development Centre, 40.

[22] Mohd Nawab, Saravamuttu, Hock and Johan. (2016). Coalitions in Collision: Malaysia's 13th General Elections. Petaling Jaya: Strategic Information \& Research Development Centre.

[23] Chin Tong, L. (2013). Middle Malaysia: Centre Ground is Battle Ground. Kuala Lumpur: Genta Media.

[24] Liow, J. (2013). PAS: Rebuilding the Party. Oxford Journal. Oxford University Press.

[25] Thuan Chye, K. (2013). The Elections Bullshit. Petaling Jaya: SIRD, 171.

[26] Lijphart, A. (2004). Constitutional Design for Divided Societies. Journal of Democracy, 15(2), 96109. http://dx.doi.org/10.1353/jod.2004.0029

[27] Yarn, D. (2002). Transnational Conflict Resolution Practice: A Brief Introduction to the Context, Issues, and Search for Best Practice in Exporting Conflict Resolution. Conflict Resolution Quarterly, 19(3), 303319. http://dx.doi.org/10.1002/crq.3890190305

[28] Fuzi, M. O. (2007). Strategies and The Tactics of Mobilisation : Opposition Political Parties in Malaysia, 1982-2003. (Ph.D). IIUM.

[29] Uhlin, A. (1998). Oposisi Berserak: Arus Deras Demoratisasi Gelombang Ketiga di Indonesia. Bandung: Penerbit Mizan.

[30] Eklof, S. (1999). Indonesian Politics in Crisis: The Long Fall of Suharto, 1996-98. Denmark: NIAS Press.

[31] Mietzner, M. (2014). How Jokowi Won and Democracy Survived. Journal of Democracy, 25(4), 111-125. http://dx.doi.org/10.1353/jod.2014.0073

[32] Tapsell, R. (2015). Indonesia's media Oligarchy and the "Jokowi Phenomenon".Indonesia, 99 (1), 29-50. http://dx.doi.org/10.1353/ind.2015.0004

[33] Warburton, E. (2016). Jokowi and the New Developmentalism. Bulletin of Indonesian Economic Studies, 52(3), 297-320. http://dx.doi.org/10.1080/00074918.2016.1249262

[34] Siegel, J. (2015). Indonesia: A Partial Appraisal. Indonesia, 100(1), 29-31. http://dx.doi.org/10.1353/ind.2015.0021

[35] Nur Atika. (2017). Coalition Among Opposition Parties in Malaysia: A Case Study of Pakatan Rakyat (PR) (2008-2016). (Master). IIUM.

[36] Syahidulamri, K. (2016). Perpuakan PAS Era Abdul Hadi Awang 2002- Jun 2015. Petaling Jaya, Kuala Lumpur: Megamind Leadership Consultancy, 53-59. 
[37] Aizat, M. M. (2011). Pemikiran Tuan Guru Nik Abdul Aziz Nik Mat. Batu Caves, Selangor, Malaysia: PTS Millennia.

[38] Malay Mail Online. (2014). In Teluk Intan, Everyone Wants A Piece Of DAP's Dyana (VIDEO). Retrieved 27 July 2016, from http://www.themalaymailonline.com/malaysia/article /in-teluk-intan-everyone-wants-a-piece-of-dapsdyana-video

[39] Malaysiakini. (2011). PRU-13: Pakatan Rakyat bincang agihan kerusi. Malaysiakini. Retrieved 18 May 2017, from http://www.malaysiakini.com/news/164732

[40] Astro Awani. (2015). Tujuh Bulan Tiada Mesyuarat Pakatan DAP PKR Dan PAS Makin Rapuh. Retrieved 3 April 2017, from http://www.astroawani.com/berita-politik/tujuhbulan-tiada-mesyuarat-pakatan-dap-pkr-dan-pasmakin-rapuh-53058

[41] Malaysiakini. (2011). PRU-13: Pakatan Rakyat bincang agihan kerusi. Malaysiakini. Retrieved 18 May 2017, from http://www.malaysiakini.com/news/164732

[42] Abdillah Noh. (2014). Malaysia 13th General Election: A Short Note on Malaysia's Continuing Battle with Ethnic Politics. Electoral Studies, 34, 266269. http://dx.doi.org/10.1016/j.electstud.2013.09.003

[43] Noriyuki, S. (2015). Ethnic Politics and Consociationalism in the 2013 Malaysian Election. Japanese Journal of Political Science, 16(02), 177194. http://dx.doi.org/10.1017/S1468109915000055

[44] Rosyidah, M. (2015). Online Opposition and Elections in Malaysia. Asian Social Science, 11(10). http://dx.doi.org/10.5539/ass.v11n10p281

[45] Ridhauddin, M. \& Nur Arfah. (2015). Tahaluf Siyasi: Antara Peluang dan Prinsip. Terengganu: Megamind Leadership Consultancy.

[46] Berita Harian. (2014). Krisis Selangor: 30 ADUN Selangor Sokong Wan Azizah Sebagai MB. Retrieved 3 April 2017, from http://www.bharian.com.my/node/490

[47] Roketkini. (2015). Pendirian DAP Tentang Isu Hudud, Presiden PAS, Dan Pakatan Rakyat. Retrieved 1 February 2017, from https://www.roketkini.com/2015/03/24/pendiriandap-tentang-isu-hudud-presiden-pas-dan-pakatanrakyat/

[48] Astro Awani. (2014). 2014 Pakatan Rakyat Dihimpit Berbagai Masalah. Retrieved 28 September 2016, from http://www.astroawani.com/sebelum2015/2014-pakatan-rakyat-dihimpit-berbagaimasalah-51150

49] Mstar. (2014). Bekas Setiausaha Politik Khalid, Faekah Keluar PKR. (2014). Retrieved 18 June 2017, from http://www.mstar.com.my/berita/beritasemasa/2014/08/11/faekah-keluar/

[50] Roketkini. (2012). Mengapa Pakatan Rakyat Perlu Selamatkan Malaysia. Retrieved 30 January 2017, from http://www.roketkini.com/2012/01/17/mengapa- pakatan-rakyat-perlu-selamatkan-malaysia-oleh-t-k$\tan /$

[51] Nur Atika. (2017). Coalition Among Opposition Parties in Malaysia: A Case Study of Pakatan Rakyat (PR) (2008-2016). (Master). IIUM

[52] Mstar. (2015). 'Hilang' Dua Pemimpin Utama Wujud Kelompangan Dalam Pakatan Rakyat. Retrieved 1 February 2017, from http://www.mstar.com.my/berita/beritasemasa/2015/02/19/kelompangan-pakatan-rakyat/

[53] Utusan Online. (2015). Anwar Kekal Dipenjara 5 Tahun. Retrieved 1 February 2017, from http://www.utusan.com.my/berita/mahkamah/anwarkekal-8232-dipenjara-5-tahun-1.58337

[54] Ridhauddin, M. \& Nur Arfah. (2015). Tahaluf Siyasi: Antara Peluang dan Prinsip. Terengganu: Megamind Leadership Consultancy.

[55] Idris, A. (2017). Bersama Kita Membangunkan Jamaah. PAS Kelantan. Kelantan.

[56] Malaysiakini. (2015). PAS: Dua Pakatan Boleh Wujud Serentak. Retrieved 1 February 2017, from http://www.malaysiakini.com/news/317240

[57] Syahidulamri, K. (2016). Perpuakan PAS Era Abdul Hadi Awang 2002- Jun 2015. Petaling Jaya, Kuala Lumpur: Megamind Leadership Consultancy, 117.

[58] Bakashmar, M. (2016). Religion and politics in Malaysia: A case for "Semi-Secularism"? International Journal of Islamic Thoughts, 5 (2), 5-26. Retrieved from http://www.ijits.net/religion-politicsmalaysia-case-semi-secularism-muhammad-rashaadbakashmar/

[59] Selangorkini. (2017). Sambut Baik BERSATU sertai PAKATAN, Langkah Tewaskan UMNO-BN. Retrieved 24 March 2017, from https://selangorkini.my/2017/03/sambut-baikbersatu-sertai-pakatan-langkah-tewaskan-umno-bn/ 